\title{
BAHAN BANGUNAN DALAM PERADABAN MANUSIA: SEBUAH TINJAUAN DALAM SEJARAH PERADABAN MANUSIA
}

\author{
Gatot Suharjanto \\ Jurusan Arsitektur, Fakultas Sains dan Teknologi, Binus University \\ Jln. K.H. Syahdan No. 9, Kemanggisan, Jakarta Barat 11480 \\ gats.id@gmail.com
}

\begin{abstract}
Building, which consists of many building materials arranged in following the designer's patter, could be stood and built in many scale, time and place. Development of the shape in building design has been changed from time to time as in time development and human ability that keeps increasing. Many buildings came from human civilization. Knowledge, social community and environment circumstances and also building material sources have huge role in developing building shapes. How far the existance of the building, it becomes retrieval benchmark in human civilization through building material usage approach in each age.
\end{abstract}

Keywords: building material, human civilization

\begin{abstract}
ABSTRAK
Bangunan, yang terdiri atas sekumpulan material bangunan yang disusun mengikuti pola gagasan si perancang, mampu berdiri dan terbangun dalam berbagai skala, waktu dan tempat. Perkembangan bentuk desain bangunan berubah dari waktu ke waktu seiring dengan kemajuan zaman dan kemampuan manusia yang juga terus bertambah. Berbagai bentuk bangunan lahir dari peradaban manusia. Ilmu pengetahuan, keadaan sosial masyarakat, kondisi lingkungan dan sumber bahan bangunan memiliki andil sangat besar dalam perkembangan bentuk-bentuk bangunan. Sejauh apa keberadaan bangunan menjadi tolok ukur penelusuran peradaban manusia akan diuraikan melalui pendekatan penggunaan bahan bangunan yang ada pada zamannya masing-masing.
\end{abstract}

Kata kunci: bahan bangunan, peradaban manusia 


\section{PENDAHULUAN}

Material bangunan adalah komponen penting yang ada dalam sebuah bangunan baik itu sebagai bahan utama konstruksi ataupun sebagai bahan penunjang konstruksi. Dengan kata lain keberadaan suatu bangunan sangat berkaitan erat dengan satu atau banyak jenis material bangunan. Penggunaan material bangunan dalam desain arsitektur memberikan kontribusi pada pencitraan bangunan itu sendiri. Para perancang, pengguna hingga pengamat bangunan senantiasa akan memberikan apresiasi yang beragam terkait dengan material yang tersusun menjadi bentuk arsitektur.

Sulistijowati (1991), memaparkan bahwa salah satu aspek yang menjadi kriteria pengelompokan (tipologi) suatu bangunan dapat di klasifikasikan berdasarkan langgam, tekstur ataupun jenis material bangunan. Teknologi membuat peradaban manusia berangsur-angsur berubah, pengetahuan tentang bahan bangunan semakin betambah, semakin ditemukan formula2 baru, semakin beragam jenis material yang bisa diproduksi manusia. Material bangunan terus berkembang seiring dengan peradaban manusia. Perkembangan tersebut tentunya membawa dampak kepada adanya fenomena perubahan dalam desain maupun bentuk sebuah bangunan arsitektur. Dengan demikian keinginan untuk mewujudkan berbagai macam rancangan arsitekturpun semakin leluasa. Maka material bangunan sangat mungkin untuk dijadikan sebagai salah satu komponen pengelompokan yang bisa di telusuri berkaitan dengan peradaban manusia dari zaman ke zaman.

Pembahasan ini dimaksudkan untuk mencari alur penggunaan material pada bangunan dari zaman ke zaman untuk tujuan memperoleh keterkaitan akan penggunaan material di setiap era dengan masing-masing peradaban dan teknologi yang dicapai oleh manusia. Kemudian dikaitkan dengan paradigma apa yang dapat disimpulkan atas penggunaan material yang ada yang terus berkembang.

\section{PEMBAHASAN}

Arsitektur berkembang dalam ruang nyata, ada di dalam kehidupan masyarakat. Sama halnya dengan ilmu-ilmu lain, selalu memiliki keadaan yang terkait dengan dinamika kehidupan masyarakat. Berarti ada hubungan imbal balik antara arsitektur dengan kehidupan masyarakat. Saling mempengaruhi antar kedua belah pihak. Dengan demikian, arsitektur disatu waktu dapat menjadi obyek sementara dilain waktu juga dapat menjadi subyek atas hubungan imbal balik itu. Sebagai subyek, seringkali arsitektur memiliki peran menentukan perubahan pada masyarakat, sementara jika ditinjau sebagai obyek, arsitektur yang muncul terkait erat dengan kemajuan peradaban manusia dimana pemahaman teknologi bahan bangunan menjadi salah satu aspek yang mempengaruhi perwujudan bangunan ataupun penataan ruang luar dengan eskalasi tertentu.

\section{Paradigma Arsitektur}

Paradigma arsitektur adalah sebuah keniscayaan bahwa setiap adanya rentang waktu dalam kehidupan manusia memiliki catatan sejarah, salah satu catatan yang dapat dijadikan faktor penilaian paradigma adalah artefak atau peninggalan-peninggalan fisik dalam setiap periode peradaban manusia. Berdasarkan hal ini, teori teori paradigma muncul dan berkembang sesuai pemahaman yang dianggap berlaku. Paradigma berarsitektur berkembang sesuai zamannya daspat digolongkan sebagai: (1) paradigma mithologi dan kosmologi; (2) paradigma estetika; (3) paradigma sosial; (4) paradigma rasionalis; (5) paradigma kultur; (6) paradigma post modernism; (7) paradigma environmentalisme.

\section{Bahan Bangunan Arsitektur}

Bangunan biasanya dikonotasikan dengan rumah, gedung ataupun segala sarana dan prasarana dalam kehidupan manusia. Termasuk didalamnya adalah konstruksi maupun rancangannya. Didalam 
perkembangannya bangunan terus berkembang sesuai dengan tingkat peradaban manusia dan kebudayaannya. Umumnya sebuah peradaban suatu bangsa dapat dilihat dari teknik teknik bangunan maupun sarana dan prasarana yang dibuat ataupun ditinggalkan oleh manusia dalam perjalanan sejarahnya.

Karena bangunan berkaitan dengan kemajuan peradaban manusia, maka dalam perjalanannya, manusia memerlukan ilmu atau teknik yang berkaitan dengan bangunan atau yang menunjang dalam membuat suatu bangunan. Perkembangan Ilmu pengetahuan tidak terlepas dari hal tersebut seperti halnya arsitektur, teknik sipil yang berkaitan dengan bangunan. Bahkan penggunaan trigonometri dalam matematika juga berkaitan dengan bangunan yang diduga digunakan pada masa Mesir kuno dalam membangun Piramida. Bahkan pada masa sekarang, bangunan bangunan berupa gedung tinggi dianggap merupakan ciri kemajuan peradaban manusia.

Pada awalnya manusia hanya memanfaatkan apa yang ada di alam sebagai sarana dan prasarana ataupun infrastruktur dalam kehidupannya. Seperti halnya memanfaatkan gua sebagai tempat tinggal. Kemudian memanfaatkan apa yang ada di alam sebagai bahan-bahan untuk membuat infrastruktur seperti halnya batu, tanah dan kayu. Kemudian setelah ditemukan bahan bahan tambang yang dapat digunakan untuk membuat alat atau benda yang menunjang sebuah bangunan seperti halnya barang logam dan mengolah bahan bahan alam seperti mengolah batuan kapur, pasir dan tanah. Dalam perkembangannya, manusia membuat bahan bahan bangunan dari hasil industri atau buatan manusia yang bahan-bahannya bakunya diambil dari alam.

\section{Material Batu}

Batu adalah bahan bangunan tertua yang dikenal manusia. Peradaban batu diperkirakan sudah ada sejak 4.000 juta tahun lalu. Menutut catatan Sejarah, batu tertua berumur sekitar 6000 tahun, penggunaan batu oleh manusia dalam struktur bangunan Mesir kuno dan Yunani merupakan salah satu rekaman yang bisa dicatat sebagai salah satu bagian dari kehidupan berbahan anorganik.

Karena batu memiliki unsur2 yang berkristal, maka batu memiliki batasan kemampuan dalam menopang beban tertentu. Dengan alasan inilah maka pembangunan bangunan batu dimasa awalnya mencari cara untuk berupaya agar batu dapat memiliki ketahanan yang maksimal. Formasi bentuk yang umum dan paling ringan dan sederhana yang digunakan dalam bangunan batu adalah dengan menumpukkan batu diatas tanah datar kemudian disusun secara bersilangan hingga membentuk beberapa elemen berupa kolom dan dinding.

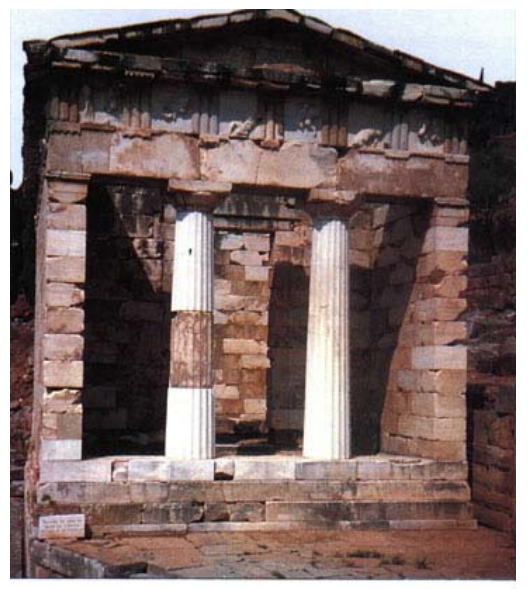

Gambar 1 Athenian Treasury, Delphi, Yunani 490 SM (Bangunan kecil yang sangat indah di salah satu sudut kota. Struktur bangunan ini adalah yang pertama yang dibangun dari marmer seluruhnya.) Sumber: Encyclopaedia Britannica (1987) 
Pada umumnya bangunan batu dibangun dari potongan-potongan batu yang disusun dan dirancang untuk dapat bertautan satu sama lain hingga membentuk sebuah bangunan batu yang menerus dan barangkali inilah awal dari era konsep prefabrication. Pengembangan arsitektur batu sejak awalnya sudah memiliki susunan yang teratur berdasarkan azas perakitan yang baik. Beberapa contoh bangunan batu telah memiliki penataan struktur batuannya berdasarkan proporsi dan ukuran tertentu.

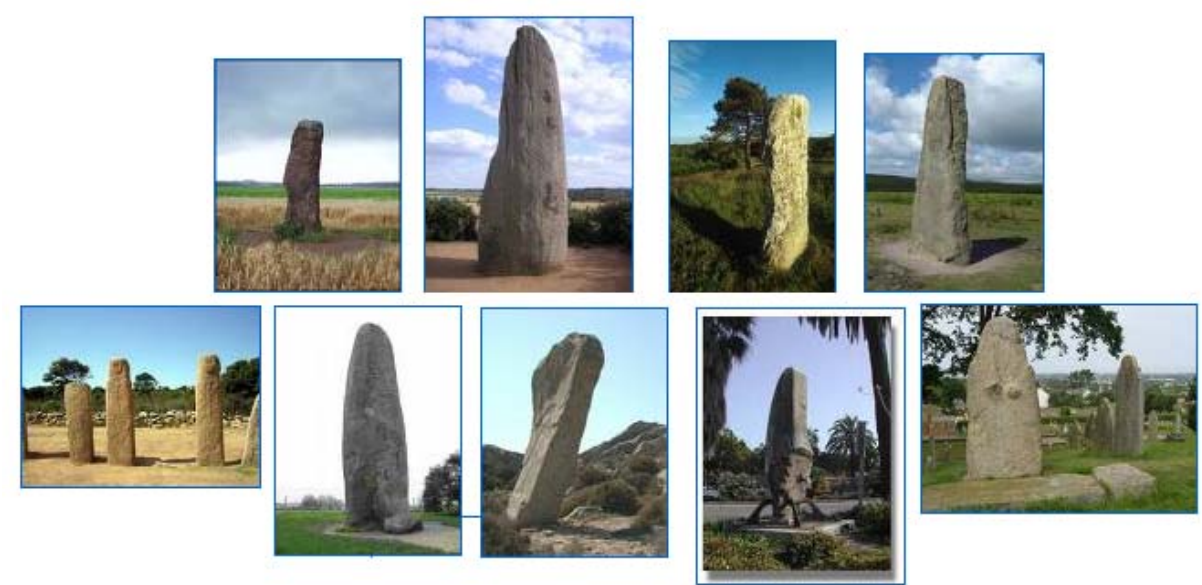

Gambar 2 Menhir (tugu batu yang didirikan sebagai tempat pemujaan untuk memperingati arwah nenek moyang)

Sangat mungkin untuk ditelusuri bahwa kecanggihan dan kekuatan konstruksi batu terus dilakukan. Kesan bahwa batu menjadi tidak berat dan tidak kaku pun terus dilakukan, terlihat dari sejarah dimana bagunan-bangunan batu pun dibuat menjulang tinggi dan memiliki berbagai macam ornamen seperti yang ditemukan dalam era Gothic di bagian utara Eropa. Hingga saat ini, bagunan itu sering digunakan sebagai tempat Lembaga Terhormat, Lembaga pemerintahan ataupun Organisasi Publik dan lain-lain.

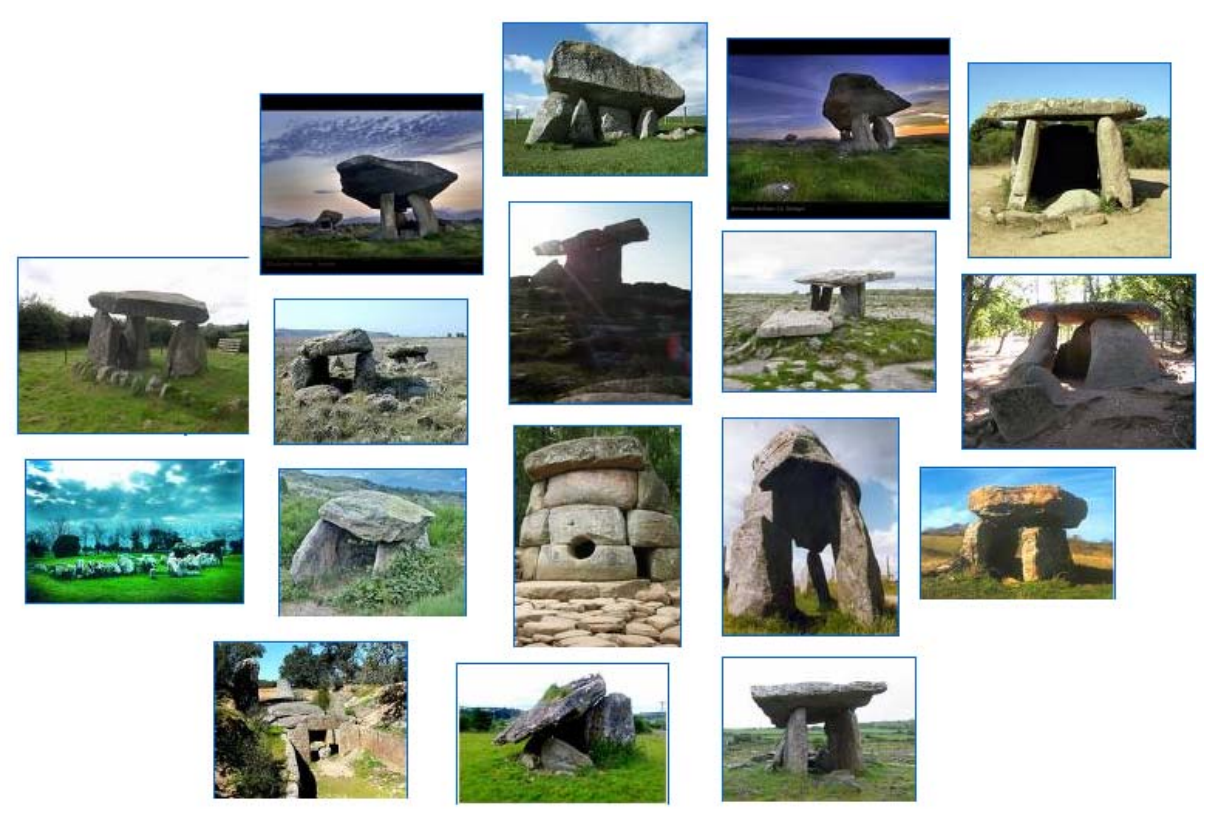

Gambar 3 Dolmen (meja batu, merupakan tempat sesaji dan pemujaan kepada roh nenek moyang, Adapula yang digunakan untuk kuburan) 
Begitu pula kelompok bangunan yang sejenis yang ditemukan di era Megalitikum, Bangunan kuburan-kuburan berumur 3000-1800 SM yang tersusun dari batu ditemukan di Perancis , beberapa contoh lain pun banyak ditemukan didaratan Eropa. Di sisi lain pemahat batu juga bekerja untuk membuat ornamen2nya seperti yang ditemukan di Jordania pada tahun 120 Masehi.

\section{Kayu}

Kayu yang merupakan bahan alami dari batang pohon memiliki manfaat yang luar biasa bagi berbagai macam kebutuhan manusia. Salah satu manfaat yang digunaan manusia adalah penggunaan kayu sebagai bahan bangunan baik untuk bahan konstruksi, ornamen hingga asesories, perkakas, dan lain sebagainya. Sebagai bahan bangunan, bukan bahan konstruksi, penggunaan kayu telah ditemukan antara tahun 665 s/d 57 SM SM. Penggunaan konstruksi sederhana mulai diterapkan disebuah dinasti di Jepang dimana secara umum arsitektur jepang yang masih berhubungan dengan arsitektur korea memiliki kesamaan hubungan kepercayaan. Beberapa bentuk yang digunakan dimasa itu adalah digunakan pada bangunan Kuil, Kedai Minum Teh, Budhist Temple dan tempat peribadatan agama Shinto.

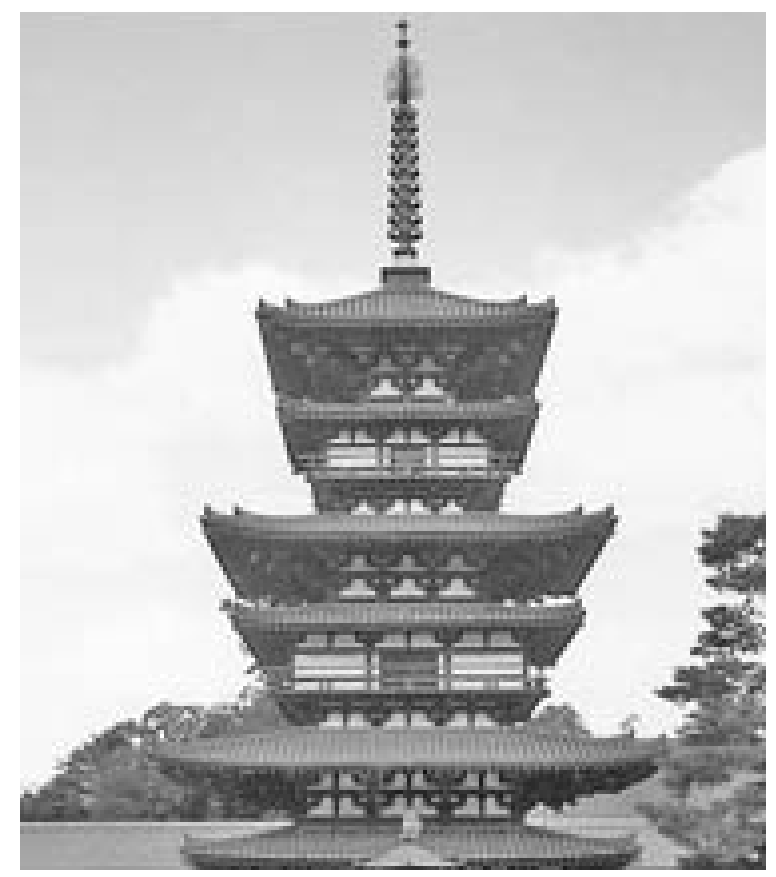

Gambar 5 Arsitektur kuno Jepang

Sumber: Aldokkan (2001)

Pada masa awal penggunaan kostruksi kayu, pemanfaatan kayu sebagai bahan konstruksi bangunan sederhana dibuat dengan kayu2 pohon secara utuh, kayu2 gelondongan maupun ranting2 yang disusun dan diikat dengan perhitungan2 tertentu. Sementara kegunaan kayu sebagai bahan konstruksi bangunan berlantai banyak ataupun berbentang lebar ditemukan pada tahun 120 Masehi di wilayah2 yang memiliki hutan tropis dan sub tropis. Seiring dengan bertambahnya ilmu pengetahuan, dimana manusia mulai memikirkan dan mempertimbangkan metode dan prosedur pemanfaatan kayu yang antara lain harus memenuhi syarat : mampu menahan bermacam-macam beban yang bekerja dengan aman dalam jangka waktu yang direncanakan; mempunyai ketahanan dan keawetan yang memadai melebihi umur pakainya; serta mempunyai ukuran penampang dan panjang yang sesuai dengan pemakainnya dalam konstruksi. 


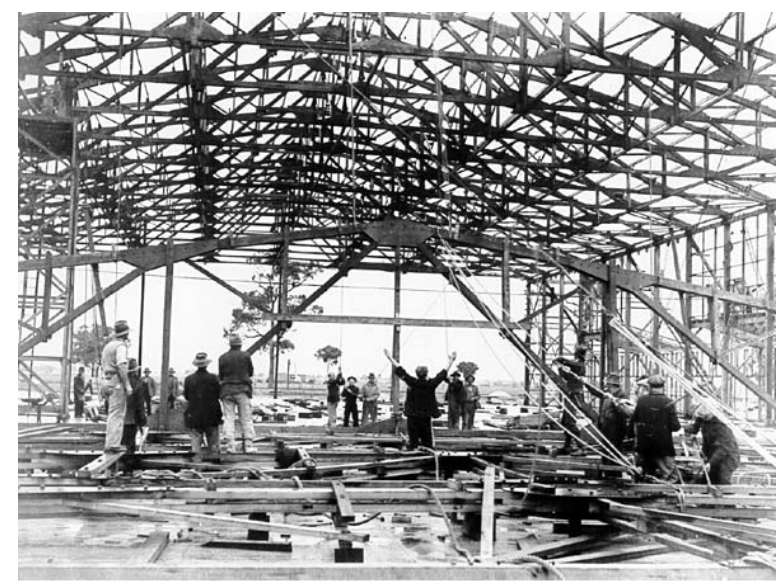

39. $6 \mathrm{~m}\left(130^{\prime}\right)$ span hangar under construction at Tocumwal, NSW

Gambar 6 Konstruksi hanggar di New South Wales, Australia

Dalam penggunaannya, kayu dipengaruhi oleh sifat-sifatnya, yaitu sifat fisis, mekanis, anatomis, kimia maupun sifat lainnya. Sifat tersebut dipengaruhi oleh jenis kayu, umur pohon, letak kayu dalam pohon, perbedaan tempat tumbuh serta faktor lainnya yang mempengaruhi pertumbuhannya. Sebagai bahan bangunan, maka kayu harus memenuhi syarat tertentu seperti kerapatan, kembang susut, kekuatan dan keawetannya. Selain digunakan sebagai bahan konstruksi dari bangunan itu sendiri, kayu merupakan komponen penting dari yang digunakan sebagai bahan penumpu bangunan (scafolding), sebagai bahan untuk alas pelapis beton, alas kerja (formwork) untuk pemasangan baja dan lain lain.

\section{Batu Bata}

Batu bata adalah bahan bangunan campuran yang pertama kali digunakan oleh manusia. Ada banyak alasan mengapa batu bata telah bertahan dibuat dan digunakan sejak zaman Mesir. Secara ekonomi batu bata memiliki harga yang relatif murah dan terjangkau, bahan baku pembuatannya pun sangat mudah diperoleh, mudah diproduksi dengan jumlah banyak dengan standard yang sama, memiliki kemampuan sebagai bahan bangunan yang tahan lama dan juga sebagai bahan pelapis insulasi. Yang lebih penting dari itu adalah bahwa bahan material bangunan ini menjadi semakin dekat hubungannya dengan seluruh lapisan masyarakat, baik masyarakat berstrata bangsawan maupun strata paling bawah. Semua manusia mampu membuat tempat tinggalnya dengan mudah, murah dan efisien dengan skala yang lebih proporsional seukuran kebutuhan manusia.

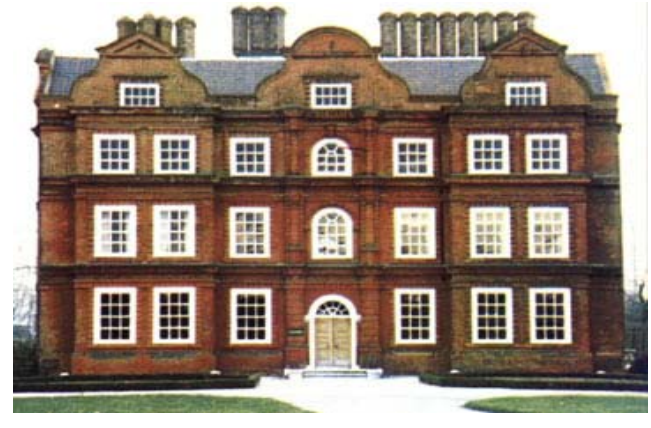

(a)

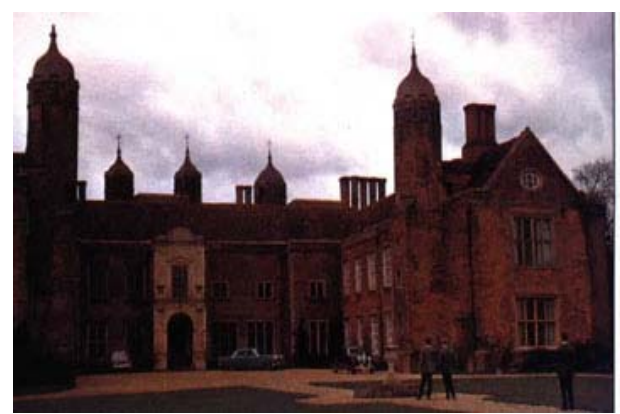

(b)

Gambar 6(a) Melford Hall, di Suffolk, Inggris (Batu bata merah dibangun di masa parlemen abad 16 Masehi); Gambar 6(b) Rumah Belanda (Contoh awal bangunan yang menggunakan bata merah)

Sumber: Encyclopaedia Britannica (1987) 

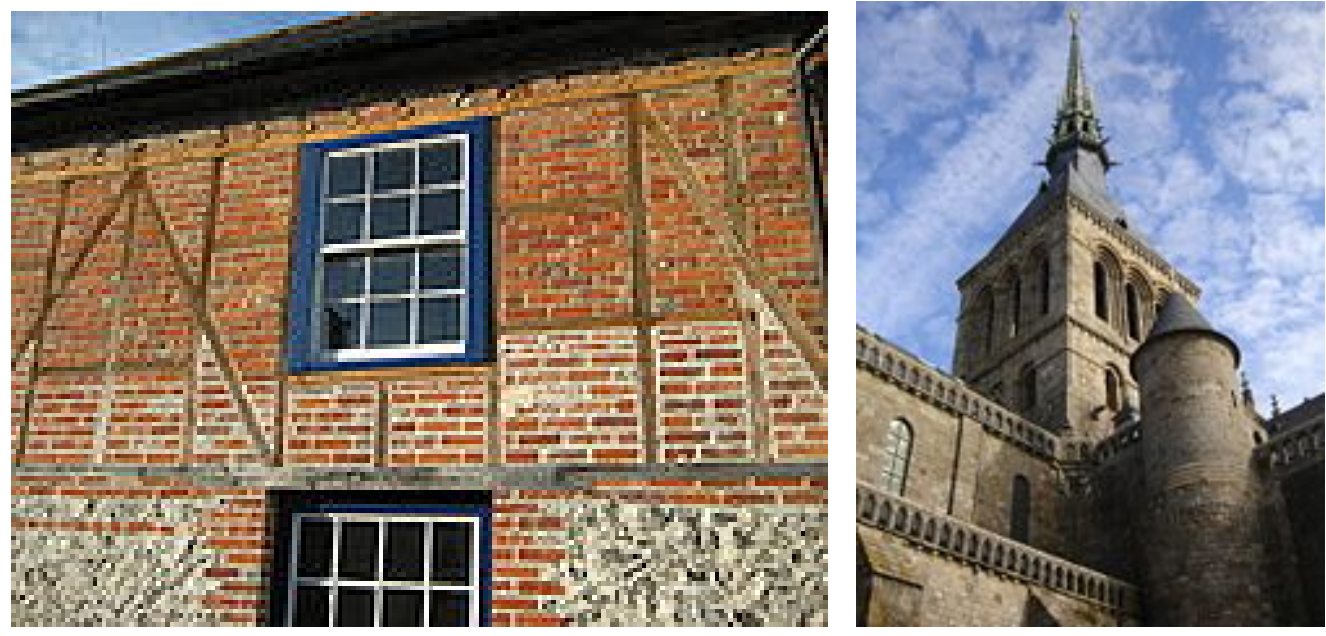

Gambar 7 Contoh lain penggunaan batu bata

\section{Besi}

Tanda-tanda awal penggunaan besi ditemukan diwilayah Sumeria dan Mesir, sekitar 4000 SM, benda kecil, seperti mata lembing dan perhiasan, dihasilkan dari besi yang diperoleh dari material meteor. Sekitar 3000 SM hingga 2000 SM, tercatat banyak objek besi yang diperoleh di Mesopotamia, Anatolia, dan Mesir. Pada 1600 SM hingga 1200 SM, besi digunakan secara lebih meluas di Timur Tengah.

Di China besi pertama yang digunakan juga merpakan besi meteor, dengan bukti arkeologi mengenai besi tempa muncul di barat laut, pada abad ke-8 SM. Benda2 tersebut dibuat dengan besi tempa, dibuat melalui proses yang sama dengan yang dibuat di Timur Tengah dan Eropa.

Pada tahun-tahun terakhir Dinasti Zhou (550 BC), teknologi tanur (pembakaran dengan suhu tinggi mencapai 1300 derajat) mulai berkembang hinga upaya untuk membuat besi tuang atau besi mentah sudah dapat. Perkembangan terus bertambah hingga sekitar tahun $221 \mathrm{M}$ di zaman dinasti Sinasti Qin.

Sementara di wilayah Eropah, kemampuan dalam teknologi peleburan besi masih jauh dibawah dinasti di China dimana mereka baru mampu mencapai suhu sekitar 1000 derajat saja. Sebahagian besar penemuan besi di Abad Pertengahan, di Eropa Barat, besi masih dibuat dengan metode penempaan. Sedangkan Contoh besi tuang yang paling awal di Eropa dijumpai di Lapphyttan dan Vinarhyttan, wilyah Swedia antara tahun 1150 hingga 1350. Bukti tersebut terlihat dari penemuan senjata seperti meriam dan peluru2nya. Pada akhir abad 17 pengembangan peleburan besi mencapai puncak awalnya di Eropa hingga terjadi revolusi Industri besar besaran.

Pemanfaatan besi pada bangunan masih sebatas pada keperluan pelengkap ataupun peralatan bangunan. Tercatat penggunaan material besi masih sebatas sebagai bahan perlengkapan pintu dan jendela sepeti engsel, kunci dan railing tangga atau balkon dsb (ironmongery) hingga abad 17. Sementara penggunaan besi pada konstruksi bangunan dimulai pada akhir abad 17. Tercatat jembatan besi di buat pada tahun 1779. Dan Kolom Cast Iron pada bangunan di Eropa di zaman Kerajaan Sir Goerge III pada abad 18. 


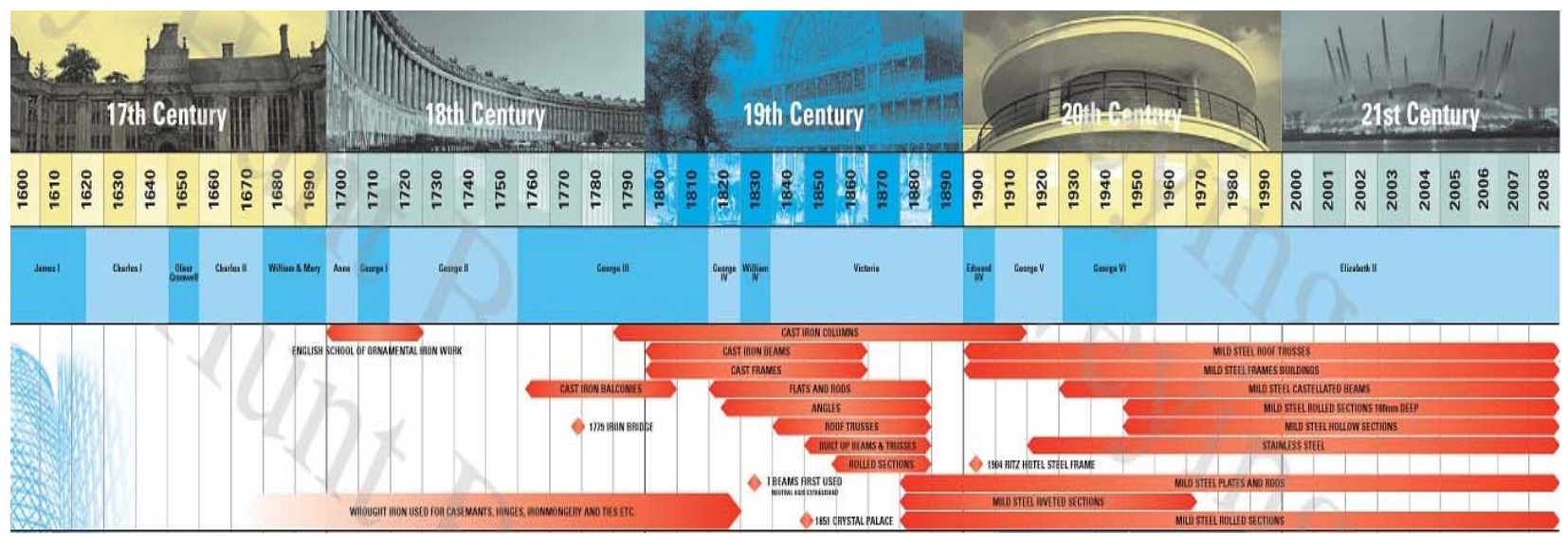

Gambar 8 Periode sejarah penggunaan besi

\section{Beton}

Beton adalah material yang digunakan sebagai bahan konstruksi bangunan, terdiri atas material padat yang terbuat dari campuran kimiawi yang disebut aggregate (umumnya terdiri atas campuran kerikil dan bermacam macam jenis pasir) yang dicampur bersama semen dan air. Masyarakat Assyrians dan Babilonia menggunakan tanah liat sebagai bahan perekat (semen). Masyarakat Mesir menggunakan asam dan gypsum. Pada tahun 1756, Seorang insinyur asal inggris, John Smeaton berhasil membuat beton modern (semen hidrolik) dengan menambah campuran kimia agregat dan memcampur serbuk batu bata ke dalam semen. Pada tahun 1824 seorang penemu dari Inggris, Joseph Aspdin menemukan semen portland, sebagai bahan dasar campuran yang dominan sebagai pembentuk beton. Joseph Aspdin menciptakan semen buatan dengan cara membakar batu cadas dengan tanah liat sekaligus. Proses pembakaran mengubah partikel kimiawi dari material tersebut sehingga menghasilkan campuran semen yang lebih kuat dari jenis semen biasa.

Bahan campuran lain selain semen dalam beton adalah agregat. Agregat terdiri atas pasir, pecahan batu kali, kerikil, abu, tanah liat yang dibakar. Agregat yang halus biasanya digunakan untuk diterapkan pada konstruksi lantai (slab) atau untuk menghasilkan permukaan beton yang halus. Sementara agregat yang kasar digunakan untuk konstruksi beton masif.

Beton yang dilengkapi dengan batangan besi disebut sebagai beton bertulang. Jenis beton bertulang ini dikembangkan pada tahun 1849 oleh Joseph Monier, dan mendapatkan hak paten pada tahun 1867. Berkat temuannya lah maka hingga saat ini bahan bangunan beton banyak digunakan untuk membuat konstruksi bangunan dengan berbagai macam bentuk.
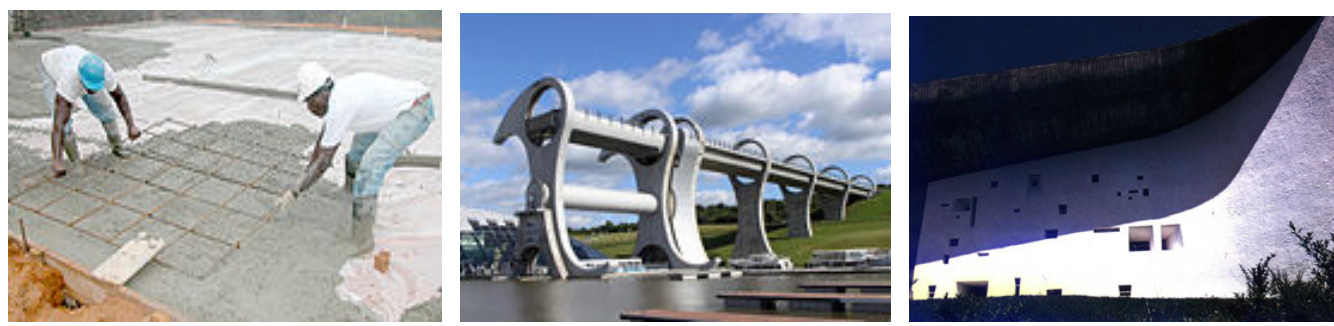

Gambar 9 Pemanfaatan bahan beton untuk berbagai jenis bentuk. Sumber: Encyclopaedia Britannica (1987) 


\section{Kaca}

Kaca alami sudah aja sejak awal kehidupan, berbentuk batuan yang meleleh karena fonomena suhu tinggi yang dipengaruhi oleh proses vulkanik, petir dan juga meteor. Lalu berangsur-angsur mendingin. Obyek kaca yang buatan manusia pertama kali umumnya berentuk manik-manik kaca non transparan ditemukan di Mesir dan Mesopotamia Timur pada sekitar tahun 3500 SM. Pada milenium ketiga, di pusat Mesopotamia, bahan baku dasar dari kaca digunakan untuk memproduksi pot dan vas bunga.

Serpihan kaca vas bunga tertua berasal yang berasal dari industri kaca hollow ditemukan di abad 16 di sekitar Mesopotamia. Jenis kaca hollow ini juga berkembang pada rentang waktu yang sama di Mesir. bukti lain juga ditemukan adanya bekas industri pembuatan kaca yang disinyalir merupakan industri rakyat di Mycenae (Yunani), dan Cina dan Tyrol bagian utara. Setelah abad 15, Masyarakat di sekitar Mesir berhasil menemukan cara meleburkan bahan kaca untuk bisa ditempelkan kedalam benda benda kerajinan lainnya, pada bongkahan batu dan sebagainya yang biasa digunakan sebagai tanda kehormatan itu. Contoh barang pecah belah Mesir yang paling awal adalah tiga vas bunga di zaman Firaun Thoutmosis III (1504-1450 SM).

Ada sedikit bukti lebih lanjut di abad ke-9 SM, dimana saat itu pengrajin kaca dari Mesir kembali ke Mesopotamia. Kemudian selama kurun waktu 500 tahun berikutnya, produksi kaca terpusat di Alessandria, kemudian menyebar sampai ke Italia. Buku manuskrip manual pengrajin kaca ditemukan disekitar tahun 650 SM. Petunjuk tentang cara pembuatan kaca terdapat dalam tablet yang disimpan di perpustakaan raja Assyrian Ashurbanipal (669-626 SM). Sebuah terobosan besar dalam pembuatan kaca adalah penemuan glassblowing antara tahun 27 SM dan 14 M. Pemanfaatan logam tabung panjang dan tipis sebagai alat bantu untuk proses meniup kaca tidak banyak berubah dalam kurun waktu tersebut.

Roma banyak menyebarkan teknologi pembuatan kaca. Dengan menawarkan hubungan perdagangan, pembangunan jalan, politik dan ekonomi, Kerajaan Roma berhasil menyebarkan teknologi pembuatan kaca ke seluruh wilayah Eropa barat dan Mediterania. Selama pemerintahan kaisar Augustus, kaca mulai muncul di wilayah Italia, Prancis, Jerman dan Swiss. Kaca Roma bahkan telah ditemukan di wilayah Cina, yang dikirim oleh para edagang di sepanjang rute sutra. Orang orang Romawi lah yang mulai memperkenalkan kaca dan menggunakannya untuk keperluan arsitektur, dengan penemuan kaca transparan (melalui pengenalan manganese oksida) di Alexandria sekitar 100 M. Digunakan kaca untuk jendela, meski baru sebatas kualitas transparansi yang rendah. Namun kaca jenis inipun hanya dapat ditemukan dalam bangunan penting di Roma dan bangunan-bangunan mewah di kota Herculaneum dan Pompeii. Dengan pembagian geografis kerajaan-kerajaan yang ada, pengrajin kaca mulai bermigrasi, dan barang pecah belah belahan timur dan barat secara bertahap mulai menunjukkan identitasnya masing-masing.

Penggalian arkeologi di Pulau Torcello dekat Venesia, Italia, telah menemukan benda-benda kaca pada akhir tahun 7 dan awal tahun ke 8 Masehi yang menjadi bukti adanya produksi kaca di era perubahan dari zaman kuno menuju abad pertengahan. Menjelang tahun 1000, perubahan teknik membuat kaca secara signifikan terjadi di Eropa. Mengingat kesulitan dalam impor bahan baku, soda kaca secara bertahap telah digantikan oleh kaca yang dibuat dengan garam abu hasil perolehan dari pembakaran pohon.

Abad ke-11 yang juga bersamaan dengan perkembangan produksi kaca di Jerman, ditemukanlah teknik lembaran2 kaca. Dengan teknik ini, pengembangan lebih lanjut muncul dalam bentuk gabungan antar lembaran dan umunya juga ditambahkan dengan berbagai jenis warna pada kaca. Sering disebut sebagai kaca patri (perca) yang ber-glazur dan dianggap mewakili kemewahan, yang ditemukan pada bangunan istana kerajaan dan gereja. 
Pada Abad Pertengahan, kota Venice Italia berperan sebagai pusat pengrajin kaca dari dunia barat. Pedagang dan pengusaha disana berhubungan dengan mitra mereka hingga ke Syria dan mulai dipengaruhi oleh seni Islam. Pada paruh kedua abad ke 15, para pengrajin mulai membuat kaca dengan menggunakan kuarsa pasir dan garam abu dari tanaman laut terutama untuk memproduksi kristal murni. Perkembangan kristal mulai merambah didaratan Eropa dan teknik pembuatannya pun semakin baik. Dimana kaca sudah mulai di grafir atau diukir.

Pada 1688, di Prancis, baru dikembangkan proses produksi kaca piring, terutama untuk digunakan sebagai cermin, yang mempunyai kualitas optik yang memadai. Produksi kaca sudah dibuat dengan menggunakan teknologi mesin-mesin uap. Lembaran kaca dengan ukuran lebar dan rata sudah bisa diproduksi. Sekitar akhir Perang Dunia I, di Belgia dikembangkan sebuah proses di mana lembaran kaca sudah bisa dibuat lebih tebal. Pada 1910, kaca sudah mulai dapat disisipkan seluloida (bahan lapisan antara dua lembar kaca) yang dapat berfungsi sebagai bahan penguat kaca. Proses yang dikembangkan setelah Perang Dunia Kedua oleh Pilkington Brothers Ltd, dan diperkenalkan pada 1959, berhasil membuat kaca optik dengan kualitas plat kaca.
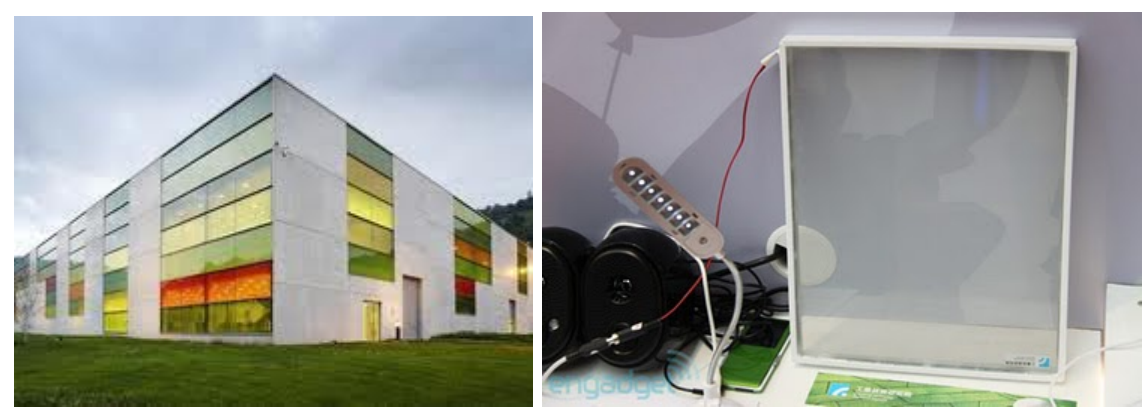

Gambar 10 Penggunaan kaca panel surya

Dan kini bahan kaca sudah semakin kaya, berbagai bentuk dan model sudah menghiasi gedung dan bangunan bangunan pencakar langit maupun bangunan berbentang lebar, bahkan saat ini kaca sudah dilengkapi dengan kemampuan dirinya untuk menjadi bahan penampung energy matahari dengan panel panel surya (Gambar 10) yang telah ditanamkan dalam kaca.
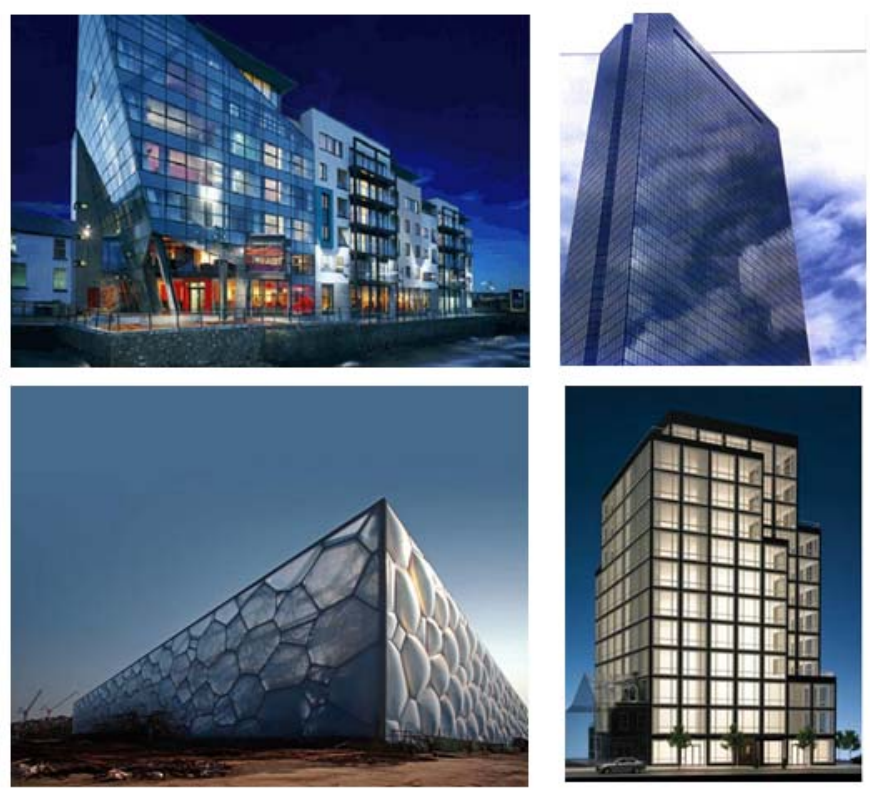

Gambar 11 Pemanfaatan bahan kaca untuk berbagai jenis bentuk.bangunan Sumber: Encyclopaedia Britannica (1987) 


\section{Material Plastik}

Proyek Rumah Plasik pertama kali muncul di tahun 1953 ketika salah satu produsen plastik terbesar Monsento Chemical Company memberikan sponsor penuh kepada para peneliti di Massaccusset Institute untuk membuat sebuah bangunan yang memiliki bahan material utama dari plastik.
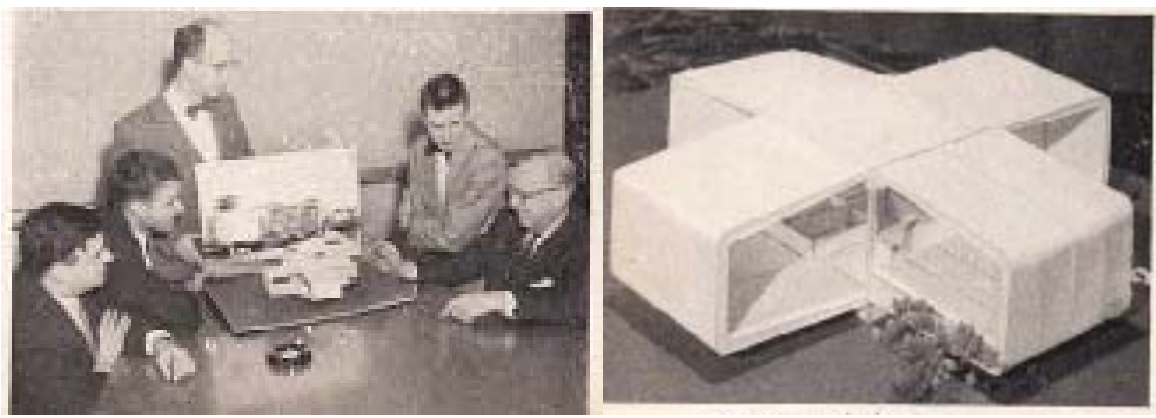

Gambar 12 Para perancang dan Model rancangan rumah plastik yang memperlihatkan bentuk 4 sayap kantilever melayang dari pusat pondasi ditengah tengah bangunan

Alasan utama penelitian tersebut adalah untuk memberikan sentuhan bentuk serta ketahanan bangunan yang lebih lama, perawatan yang lebih mudah serta tentu saja keuntungan financial dari produsen plastik sangat menggiurkan jika seandainya bahan ini menjadi modul utama dalam rancangan bangunan rumah. Alasan lain adalah karena produk temuan dari bahan plastik tengah menjadi trend dan mudah dibentuk dan diproduksi dengan cepat dan murah. Proyek tersebut dinyatakan berhasil dan menjadi inspirasi untuk memahanfaatkan bahan plastik sebagai bahan bahan pengganti kayu dan besi. Bahkan hingga saat ini keberadaan plastik dalam bangunan masih terasa. Demikian juga bagi manusia modern yang kemudian merasa bahwa plastik merupakan bahan yang tidak bisa terurai sehingga berdampak buruk bagi lingkungannya, mereka kemudian berusaha untuk memanfaatkan bahan bahan plastik bekas untuk dijadikan sebagai bahan konstruksi pengganti bata.

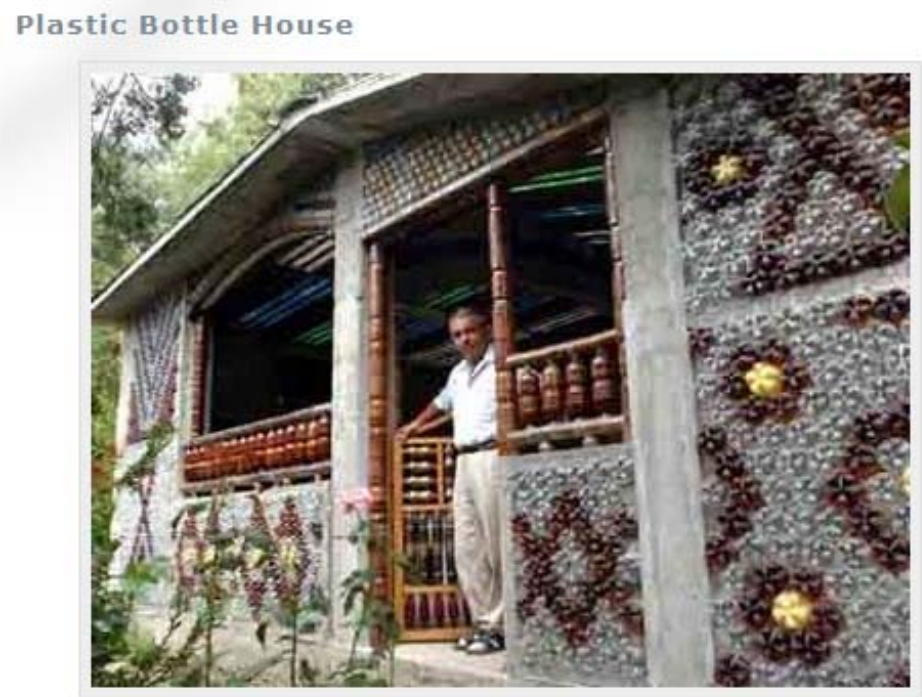

Gambar 13 Rumah botol plastik bekas 


\section{PENUTUP}

Sebagai obyek, arsitektur yang muncul berkaitan dengan peradaban manusia yang muncul berupa wujud bangunan ataupun penataan ruang luar dengan eskalasi tertentu dan material tertentu. Dalam hal ini bisa dikatakan bahwa arsitektur yang tergolong sebagai obyek rupanya sangat dipengaruhi oleh peradaban manusia dimana bentuk arsitektur sangat jelas bersandar akan keberadaan teknologi bahan bangunan di zamannya, yaitu: (1) zaman batu awal, memiliki kecenderungan bangunan tunggal dan banyak dikaitkan dengan Mitologi dan Kosmos; (2) zaman batu pertengahan, memiliki kecenderungan sebagai bangunan sakral dan penuh keagungan (era Roman, Renaisance, dan sebagainya) ditandai dengan ukiran dan langgam yang memenuhi keinginan untuk mencapai aspek keindahan; (3) periode pemanfaatan kayu sebagai bahan konstruksi bangunan memiliki paradigma kebudayaan atau paradigma sosial, di mana kayu menjadi susunan konstruksi yang dikemas untuk hunian di wilayah tropis dan subtropis dengan unsur kebudayaan setempat; (4) periode batu bata menandai awal pembuatan bangunan untuk seluruh lapisan masyarakat, pun dipengaruhi oleh aspek sosial dan kebudayaan; (5) periode besi sebagai bahan bangunan berada dalam paradigma memiliki rentang panjang yang berubah dan penggunaan paling banyak adalah sejak abad 18 hingga kini, menjadikan arsitektur dapat terbentang bebas dan sebebas-bebasnya, besi menjadikan sandaran bagi kekuatan struktur atas keinginan karya aritektur yang beragam; (6) penemuan beton, menambah khasanah dalam berarsitektur, dikombinasikan dengan besi menjadikannya luar biasa luwes, bangunan berbentang lebar dan mencakar langit banyak dijumpai dalam periode ini, bentuk bangunan berbentuk ekspresif dan terkesan tidak mengacu kepada perdebatan logika pun bermunculan, Era dekonstruksi, parametrik design, sculpture building dan lain2 dalam skala besar serta merta hadir dalam dunia arsitektur modern hingga era abad 21 ini; dan (7) kaca dan plastik, bahan bangunan yang semula hanya terpakai sebagai asesories belaka, kini pun telah digunakan sebagai unsur utama dalam bangunan di kehidupan manusia modern.

Paradigma kebebasan berekspresi adalah barangkali sebuah penyematan yang cocok pada era abad 21 ini dan seterusnya, dimana seluruh material bangunan sudah dapat dibuat dengan bebagai macam klasifikasi, semua material buatan berbahan sintetis sudah bisa diproduksi, alhasil bangunan dalam bentuk apa pun bisa diwujudkan oleh sang arsitek.

\section{DAFTAR PUSTAKA}

Encyclopaedia Britannica. (1987). The new encyclopaedia Britannica. Michigan: USA: Encyclopaedia Britannica.

Sulistijowati, M. (1991). Tipologi arsitektur pada rumah kolonial surabaya (dengan kasus perumahan plampitan dan sekitarnya). Tidak dipublikasikan. Surabaya: Pusat Penelitian Institut Teknologi Sepuluh November. 